\title{
Staking Options for Sustainable Yam Production in Ghana
}

\author{
Eric Owusu Danquah ${ }^{1}$, Stella A. Ennin ${ }^{1}$, Joseph N. L. Lamptey ${ }^{1} \&$ Particia P. Acheampong ${ }^{1}$ \\ ${ }^{1}$ Council for Scientific and Industrial Research- Crops Research Institute, Kumasi, Ghana \\ Correspondence: Eric Owusu Danquah, CSIR- Crops Research Institute, Kumasi, Ghana. Tel: 233-266-197-247/ \\ 242-357-061. E-mail: ericdany7@gmail.com
}

$\begin{aligned} & \text { Received: November 19, } 2014 \\ & \text { Accepted: December 16, } 2014 \quad \text { Online Published: December 23, } 2014 \\ & \text { doi:10.5539/sar.v4n1p106 }\end{aligned} \quad$ URL: http://dx.doi.org/10.5539/sar.v4n1p106

\begin{abstract}
The study evaluated staking options to address the problem of deforestation for sustainable yam production in the Forest and Forest-Savannah Transition zones of Ghana. A split-plot design with three yam varieties (Dente, Water Yam and TDR95/19177 line) and three staking options (No staking, Vertical staking and Trellis with 50\% and 30\% number of vertical stakes for 2012 and 2013 respectively) as main plots and subplots respectively were used. Results revealed a significant $(P \leq 0.05)$ interaction between yam variety and staking options on yam tuber yields in both locations and years. While water yam had similar tuber yields under all staking options, Dente and TDR95/19177 under no staking had significant yield reductions ranging from 37 to $65 \%$ compared to the other staking options. The observed yield reduction under no staking of Dente and TDR95/19177 could be attributed to higher incidence of yam mosaic virus leading to significantly lower fresh leaf biomass production. Reducing the number of stakes in trellis to as low as $30 \%$ of the vertical/optimum staking option did not result in a significant reduction in tuber yields for TDR95/19177 and Water yam. The economic analysis revealed that it is more profitable to produce water yam and TDR95/19177 under no staking and trellis $(50 \%$ and $30 \%$ number of optimum staking) respectively in both locations. The results suggest trellis/minimum staking can be used to minimize the use of stakes, yam mosaic virus disease infection and for sustainable yam production in the face of climate change.
\end{abstract}

Keywords: climate change, deforestation, trellis staking, yam

\section{Introduction}

Yam is an important staple food crop and currently a major non-traditional export crop in Ghana. It is one of the two major root crops produced and consumed in Ghana and West Africa. For more than a decade, yam production and export in Ghana has ranked third in the world and first in Africa and contributes about $16 \%$ to the National Agricultural Gross Domestic Product (FAOSTAT, 2012). In Ghana, yam is mostly produced in the Forest-Savanna Transition and the Guinea Savanna zones. In the Forest-Savanna Transition zone, where trees and shrubs are not scarce as compared to the Guinea Savannah, farmers during land preparation leave selected trees and shrubs as stakes. Although most of the trees die upon burning, they are still used as stakes (Wholey \& Haynes, 1971; Asante, 1996). In the Guinea Savannah where, stakes are scarce and difficult to obtain, farmers are not able to provide support for their yams, thereby affecting yields (Asante, 1996). However, with the increase in population and pressure on the limited land resources, farmers are compelled to cultivate on the same piece of land year after year. This has resulted in scarcity of stakes for yam production even in the Forest-Savannah zones (Akwag et al., 2000; EPA 2003; Ennin et al., 2014). Farmers would therefore search and use any available trees and shrubs as stakes to support their yam production thereby contributing significantly to deforestation. To address this major constraint of staking on yam production, any technique that would bring about a drastic reduction in the number of stakes used per hectare without a correspondent reduction in yields would be a welcome relief for farmers and for large-scale production for both the local and the export market. The objective of the study was to evaluate staking options (optimum number of stakes, $30 \%$ and $50 \%$ of optimum stakes) to suggest alternatives for sustainable yam production. This is to address the problem of scarcity of stakes and deforestation associated with yam production in Ghana.

\section{Materials and Method}

The study was conducted at Fumesua and Ejura in the Forest and Forest-Savanna Transition agro-ecological zones of Ghana, respectively in 2012 with $50 \%$ number stakes used in vertical staking and in 2013 with $30 \%$ 
number of stakes used in vertical staking. The experimental design was a split-plot with three replications. Yam varieties, (Dente, (white yam), Matches (water yam) and TDR95/19177 (a promising white yam line with a potential for high yields under no staking, (Otoo et al., 2008)) as the main plot treatments and staking options (Vertical staking, Trellis staking (50\% or $30 \%$ number of stakes used in vertical staking) and No staking) as sub plot treatments. Poultry manure was applied at $3 \mathrm{t} / \mathrm{ha}$ on the fields before ploughing and harrowing. Yam seeds were planted on ridges of 40-45 cm height. Each plot had an area of $144 \mathrm{~m}^{2}$ with ten ridges and $1.2 \mathrm{~m}$ spacing between them. Yams were planted at $1.2 \mathrm{~m}$ between them on each ridge. Yam mini setts of about $350 \mathrm{~g}$ were treated with Dursban (Chlorpyrifos at $80 \mathrm{ml}$ ) an insecticide and Mancozeb , a fungicide (Dithiocarbamate 80\%; $120 \mathrm{~g}$ ) in 151 of water before planting at the onset of the rains (March) 2012 and 2013. Chemical fertilizer 22.5-22.5-30 N-P $\mathrm{P}_{2} \mathrm{O}_{5}-\mathrm{K}_{2} \mathrm{O} \mathrm{kg} /$ ha were applied 11-12 weeks after planting (Bulking stage). The three yam varieties under the different staking options were also evaluated for the incidence and severity of yam mosaic virus. The disease assessment was done at five months after planting (MAP) at Fumesua and six months after planting (MAP) at Ejura in 2012 and 2013. Disease severity was done by visual scoring as described by Migouna et al. (2001) and Odu et al. (2004) using a scale of 1-5 where 1 represented apparently no symptoms, 2 - mild symptoms, 3 - moderately severe symptoms, 4 - severe symptoms and 5 - very severe symptoms. Data collected for all the studies were subjected to analysis of variance at 5\% significant level using the Statistical Analysis Software (SAS, 2007).

Table 1. Agro-ecological characteristics of the site

\begin{tabular}{|c|c|c|}
\hline \multirow{2}{*}{ Characteristics } & \multicolumn{2}{|c|}{ Location } \\
\hline & Fumesua $\left(6^{\circ} 41^{\prime} \mathrm{N}, 1^{\circ} 28^{\prime} \mathrm{W}\right)$ & Ejura $\left(7^{\circ} 23^{\prime} \mathrm{N}, 1^{\circ} 21^{\prime} \mathrm{W}\right)$ \\
\hline Agro-ecological zone & Humid Forest & Forest-Savannah Transition \\
\hline Soil type & $\begin{array}{l}\text { Ferric Acrisol; Asuansi series upper top soil } \\
\text { consisted of } 5 \mathrm{~cm} \text { greyish brown sandy loam topsoil } \\
\text { of dark brown gritty clay loam }\end{array}$ & $\begin{array}{l}\text { Ferric Lixisol; Ejura series with } 20-30 \mathrm{~cm} \text { thick } \\
\text { top layer of loam soils. Soils are dark brown to } \\
\text { brown fine sandy loam }\end{array}$ \\
\hline $\begin{array}{l}\text { Temperature } \\
\left(\text { Min-Max. }{ }^{\circ} \mathrm{C} \text { ) }\right. \\
2010-2013\end{array}$ & $21-31$ & $21-34$ \\
\hline Wet season & Bimodal rainfall pattern & Bimodal rainfall pattern \\
\hline Major & March - mid August & March-mid- August \\
\hline Minor & Sept-Nov; peak in Oct & September- Nov; peak in Oct \\
\hline Total annual rainfall $(\mathrm{mm})$ & $2012(1028 \mathrm{~mm}) 2013(1226 \mathrm{~mm})$ & $2012(1114 \mathrm{~mm}) 2013(1210 \mathrm{~mm})$ \\
\hline
\end{tabular}

Adopted from Adu and Asiamah, 1992.

\section{Results}

The staking options significantly $(P \leq 0.05)$ affected the fresh leaf biomass and tuber yields of yam varieties at both Fumesua and Ejura in both years (Figures 1a, 1b, 2a, 2b, 3a \& 3b). Generally, the total yields were significantly $(P \leq 0.05)$ higher for the optimum staking option (vertical staking) of the yam varieties as compared to the non-staking option (Figures $1 \mathrm{a}, 1 \mathrm{~b}, 2 \mathrm{a} \& 2 \mathrm{~b}$ ) in both locations except water yam. However, the differences in yields for the vertical and trellis (50\% and $70 \%$ less stakes) staking options were not significantly different for TDR95/19771 as compared to Dente where significant differences were observed in the vertical and trellis staking options in both locations (Figures $1 \mathrm{a}, 1 \mathrm{~b}, 2 \mathrm{a} \& 2 \mathrm{~b}$ ). The percentage yield reduction of the no staking option with reference to vertical staking was more pronounced in Dente (48-64\%) followed by TDR95/19771 (37-45\%) with water yam having the least yield reduction (6-10\%) for both locations and years (Figures 1a,1b, 2a \& 2b). Generally, water yam produced more fresh leaf and vine biomass followed by TDR95/19771 and Dente in both locations (Figures 3a \& 3b). The yield reduction was not significantly different for TDR95/19771 with vertical and trellis staking options for both locations and years (Figures 1a, 1b, 2a and 2b). 


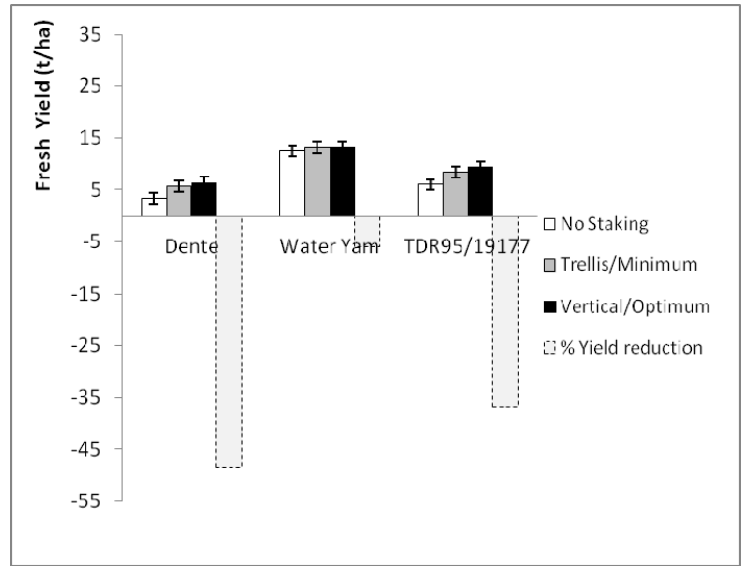

Figure 1a. Effect of staking options on tuber yield of yam, Fumesua (2012)

NB: Trellis/Minimum staking option had 50\% number of vertical staking option

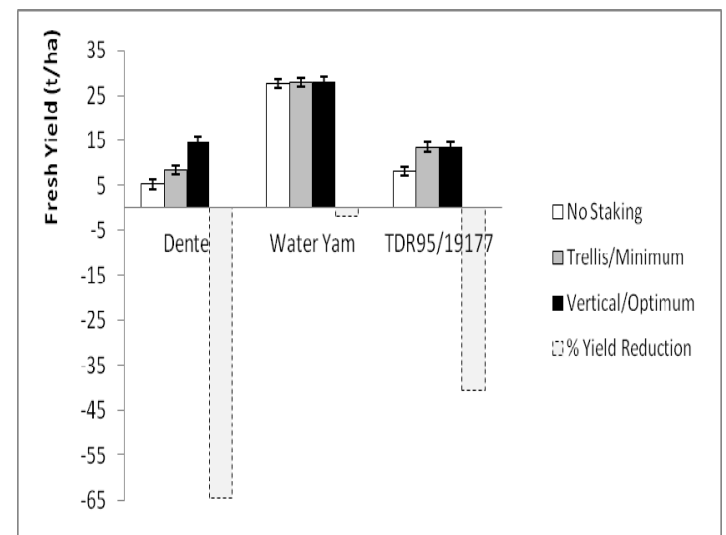

Figure 2a. Effect of staking options on tuber yield of yam, Fumesua (2013)

NB: Trellis/Minimum staking option had $30 \%$ number of vertical staking option

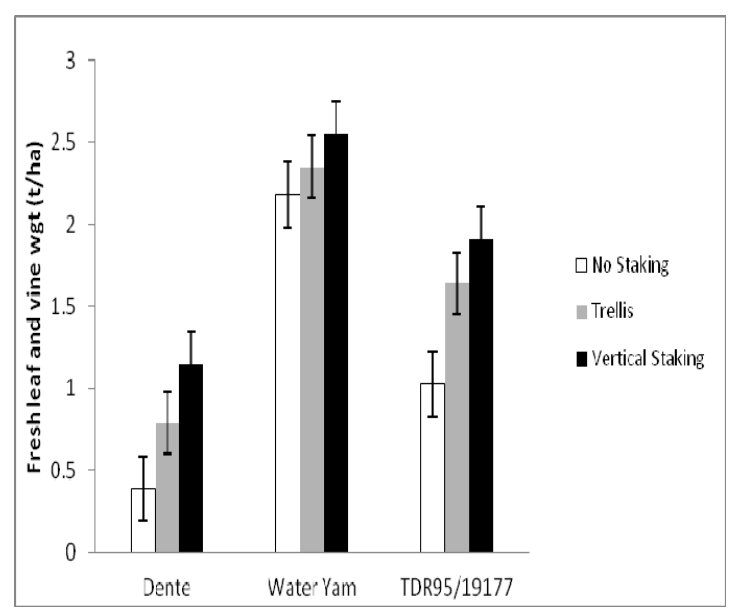

Figure 3a. Effect of staking options on fresh leaf biomass of yam varieties, Fumesua

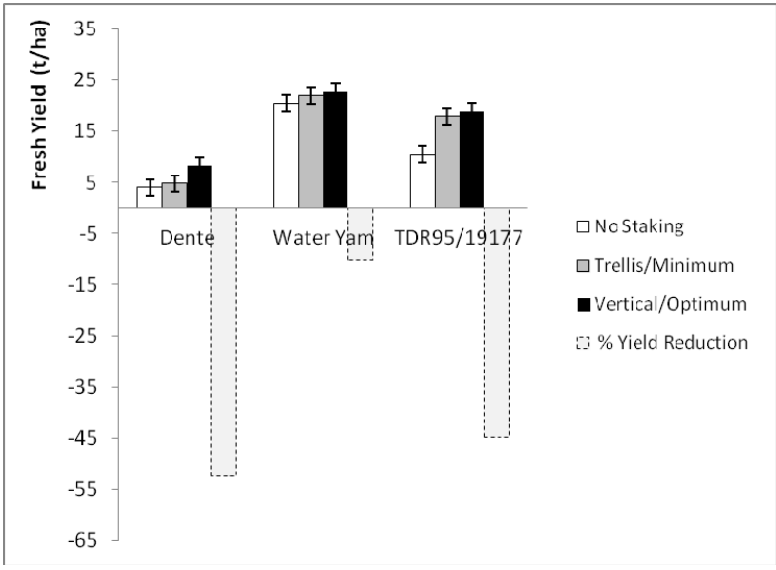

Figure 1b. Effect of staking options on tuber yield of yam, Ejura (2012)

NB: Trellis/Minimum staking option had 50\% number of vertical staking option

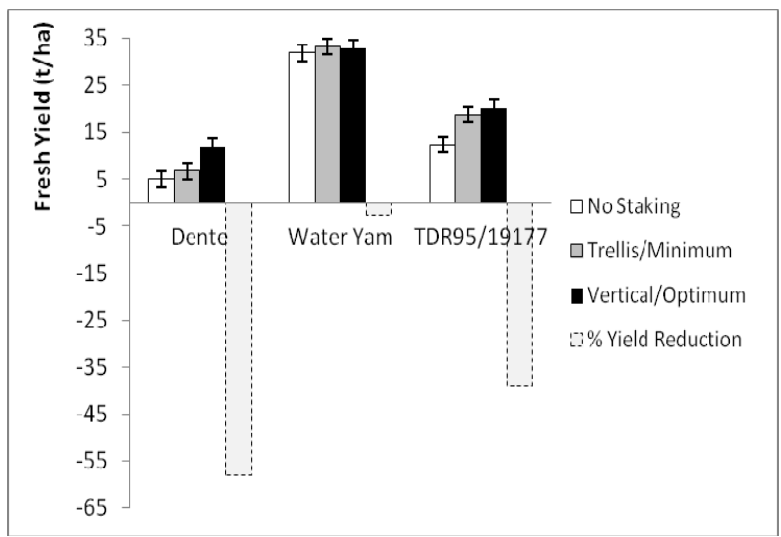

Figure 2b. Effect of staking options on tuber yield of yam, Ejura (2013)

NB: Trellis/Minimum staking option had 30\% number of vertical staking option

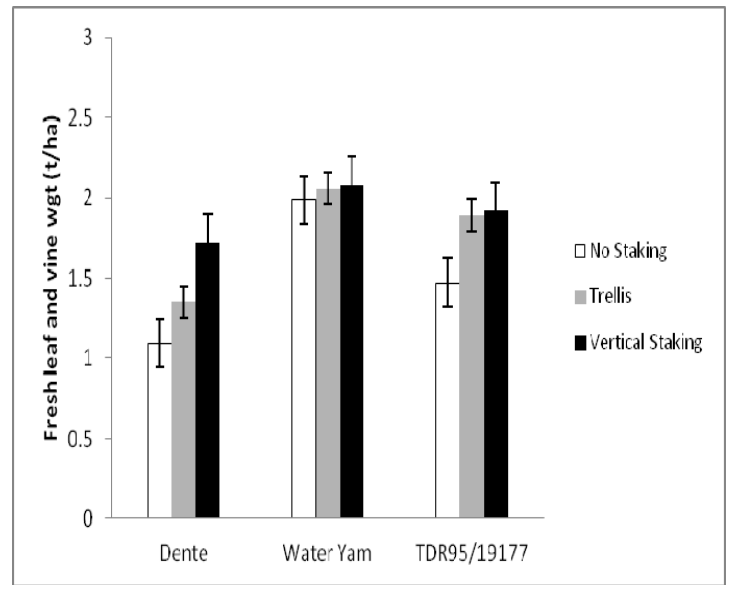

Figure 3b. Effect of staking options on fresh leaf biomass of yam varieties, Ejura

The staking options had similar effects on weed suppression, however variety significantly $(P \leq 0.05)$ affected weed suppression with TDR95/19177 suppressing weeds 34\% and 32\% more than Dente and water yam 
respectively (Figure 4). Generally, virus incidence and severity on the three varieties were higher at Ejura than Fumesua in both 2012 and 2013. Also, virus incidence and severity were higher in 2012 than 2013 in both locations. Virus incidence and severity were low on water yam irrespective of the staking options for both years and locations. Dente and TDR95/1977 subjected to no staking had significantly $(P \leq 0.05)$ higher percentage virus incidence and severity as compared to the other staking options (vertical and trellis) in both locations (Tables 2). However, values for virus incidence and severity observed for Dente and TDR95/1977 subjected to vertical and trellis staking in both locations were quite similar (Table 2).

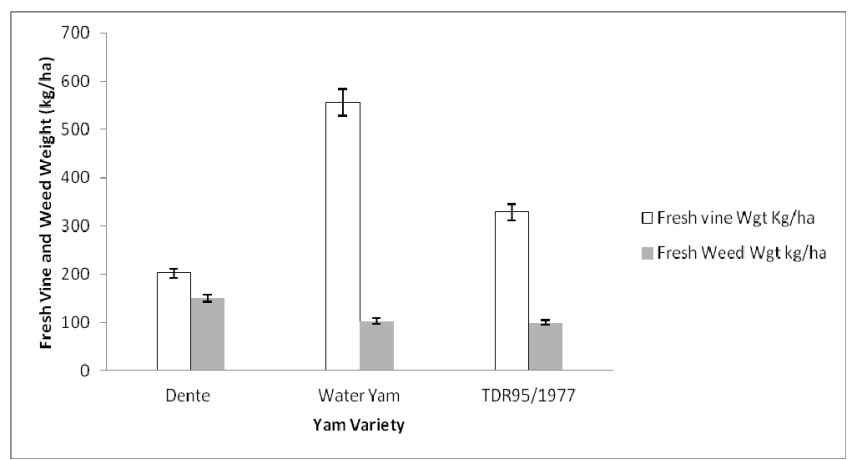

Figure 4. Biomass and weed suppression of three yam varieties (Fumesua, 2013)

Table 2. Effect of yam varieties subjected to different staking options on incidence and severity of mosaic virus, 5-6 months after planting at Fumesua and Ejura in 2012 and 2013

\begin{tabular}{|c|c|c|c|c|c|c|c|c|c|c|c|c|c|c|c|c|}
\hline \multicolumn{17}{|c|}{2012 Trellis/Minimum staking option with 50\% number of vertical/optimum staking option } \\
\hline \multicolumn{3}{|l|}{ Location } & \multicolumn{4}{|c|}{ Fumesua } & \multirow{2}{*}{\multicolumn{2}{|c|}{ Mean }} & \multicolumn{6}{|c|}{ Ejura } & \multicolumn{2}{|c|}{ Mean } \\
\hline Yam variety & \multicolumn{2}{|c|}{ Dente } & \multicolumn{2}{|c|}{ Water yam } & \multicolumn{2}{|c|}{ TDR95/19177 } & & & \multicolumn{2}{|c|}{ Dente } & \multicolumn{2}{|c|}{ Water yam } & \multicolumn{2}{|c|}{ TDR95/19177 } & \multirow{2}{*}{\multicolumn{2}{|c|}{$\% \mathrm{IN} \quad \mathrm{SE}$}} \\
\hline Mosaic Virus & $\% \mathrm{IN}$ & SE & $\% \mathrm{IN}$ & SE & $\% \mathrm{IN}$ & SE & $\% \mathrm{IN}$ & $\mathrm{SE}$ & $\% \mathrm{IN}$ & SE & $\% \mathrm{IN}$ & SE & $\% \mathrm{IN}$ & SE & & \\
\hline No staking & 42.3 & 2.8 & 3.7 & 1.7 & 75.7 & 2.4 & 40.6 & 2.3 & 95.3 & 3.3 & 10 & 1.5 & 74 & 3.7 & 59.8 & 2.8 \\
\hline Trellis & 31.7 & 2.3 & 1.7 & 1 & 48 & 2.1 & 27.1 & 1.8 & 62 & 3.2 & 5 & 1.1 & 59 & 3 & 42 & 2.4 \\
\hline Vertical & 30 & 2.3 & 0 & 1 & 47.7 & 2 & 25.9 & 1.8 & 47 & 3 & 0 & 1 & 57 & 2.7 & 34.7 & 2.2 \\
\hline Mean & 34.7 & 2.5 & 1.8 & 1.2 & 57.1 & 2.2 & 31.2 & 2 & 68 & 3.2 & 5 & 1.2 & 63.3 & 3.1 & 45.5 & 2.5 \\
\hline \multirow[t]{2}{*}{ SED } & 1.72 & 0.24 & 1.72 & 0.24 & 1.72 & 0.24 & 1.72 & 0.24 & 2.42 & 0.22 & 2.42 & 0.22 & 2.42 & 0.22 & 2.42 & 0.22 \\
\hline & \multicolumn{16}{|c|}{2013 Trellis/Minimum staking option had 30\% number of vertical staking option } \\
\hline Location & \multicolumn{6}{|c|}{ Fumesua } & \multicolumn{2}{|c|}{ Mean } & \multicolumn{6}{|c|}{ Ejura } & \multicolumn{2}{|c|}{ Mean } \\
\hline Yam Variety & \multicolumn{2}{|c|}{ Dente } & \multicolumn{2}{|c|}{ Water yam } & \multicolumn{2}{|c|}{ TDR95/19177 } & & & \multicolumn{2}{|c|}{ Dente } & \multicolumn{2}{|c|}{ Water yam } & \multicolumn{2}{|c|}{ TDR95/19177 } & & \\
\hline Mosaic Virus & $\% \mathrm{IN}$ & SE & $\% \mathrm{IN}$ & SE & $\% \mathrm{IN}$ & SE & $\% \mathrm{IN}$ & $\mathrm{SE}$ & $\% \mathrm{IN}$ & $\mathrm{SE}$ & $\% \mathrm{IN}$ & $\mathrm{SE}$ & $\% \mathrm{IN}$ & SE & $\% \mathrm{IN}$ & SE \\
\hline No staking & 15.3 & 2.8 & 0 & 1 & 21.3 & 1.8 & 36.6 & 1.9 & 63.3 & 2.5 & 3.4 & 1.3 & 36 & 3.7 & 34.2 & 2.5 \\
\hline Trellis & 9.1 & 1.8 & 0 & 1 & 5.3 & 1.1 & 4.8 & 1.3 & 30 & 2.2 & 1 & 1 & 21 & 2 & 17.3 & 1.7 \\
\hline Vertical & 5.3 & 1.7 & 0 & 1 & 3.3 & 1 & 2.9 & 1.2 & 27 & 2 & 1 & 1 & 21 & 2 & 16.3 & 1.7 \\
\hline Mean & 10 & 2.1 & 0 & 1 & 10 & 1.3 & 14.8 & 4.4 & 40.1 & 2.2 & 1.8 & 1.1 & 26 & 2.6 & 22.6 & 2 \\
\hline SED & 1.17 & 0.18 & 0 & 0.2 & 1.17 & 0.18 & 1.17 & 0.18 & 2.13 & 0.22 & 2.13 & 0.22 & 2.13 & 0.22 & 2.13 & 0.22 \\
\hline
\end{tabular}

$\%$ IN- Percentage Incidence; SE- Severity Score (1-5); 1- apparently no symptoms, 2- mild symptoms, 3- moderately severe symptoms, 4- severe symptoms and 5-very severe symptoms.

Table 3 presents the partial budgeting and cost benefit analysis of three varieties of yams under vertical staking, trellis/reduced staking and no staking options in the forest (Fumesua) and transition (Ejura) zones. Results from the $50 \%$ less stakes study in the $1^{\text {st }}$ year (2012), revealed that water yam under no staking resulted in higher benefit-cost-ratio at both Fumesua (2.3:1) and Ejura (4.2:1) compared with trellis (50\% reduced stakes) and 
vertical staking options that gave benefit-cost-ratio of $1.9: 1 ; 3.9: 1$ and $1.4: 1 ; 3.5: 1$ in Fumesua and Ejura, respectively (Table 3). For TDR95/19177 the highest benefit-cost-ratio was recorded for the trellis option in Ejura (3.4:1) whiles Fumesua had 1:1. However, in Fumesua and Ejura, the vertical staking of Dente had the highest benefit-cost-ratio $0.5: 1$ and 1:1, respectively (Table 3). When the trellis option had $30 \%$ number stakes used in vertical staking in the $2^{\text {nd }}$ year (2013), the results followed similar trend. Non-staked Water yam had the highest benefit-cost-ratio of 6.5:1 in both Fumesua and Ejura, respectively followed by TDR95/19177 on trellis with benefit-cost-ratio of 2.8:1 and 3.3:1 in Fumesua and Ejura respectively (Table 3). The vertical staking of Dente recorded 2.8:1 and 3.4:1 benefit-cost-ratio in Fumesua and Ejura (Table 3).

Table 3. Partial budget and cost benefit analysis of three yam varieties under Vertical, Trellis and no Staking options at Fumesua and Ejura

\begin{tabular}{|c|c|c|c|c|c|c|c|c|c|c|c|c|c|c|c|c|}
\hline \multirow{4}{*}{$\frac{\frac{\text { Location }}{\text { Yam Variety }}}{\text { Staking Ontio }}$} & \multicolumn{16}{|c|}{2012 Trellis/Minimum staking option with $50 \%$ number of vertical staking option } \\
\hline & \multicolumn{8}{|c|}{ Fumesua } & \multicolumn{8}{|c|}{ Ejura } \\
\hline & \multicolumn{3}{|c|}{ Dente } & \multicolumn{3}{|c|}{ Water yam } & \multicolumn{2}{|c|}{ TDR95/19177 } & \multicolumn{2}{|r|}{ Dente } & \multicolumn{3}{|c|}{ Water Yam } & \multicolumn{3}{|c|}{ TDR95/19177 } \\
\hline & Vet & Trel 1 & NS & Vet & Trel & NS & Vet & Trel NS & Vet & Trel NS & Vet & Trel & NS & Vet & Trel & NS \\
\hline Average yields $(\mathrm{kg} / \mathrm{ha})$ & 6400 & 055003 & 33001 & 12500 & 13200 & 13300 & 9500 & 88006000 & 8400 & 48004000 & 22800 & 22000 & 20500 & 19000 & 18000 & 10500 \\
\hline Adjusted yield* & 5760 & 049502 & 29701 & 11250 & 11880 & 11970 & 8550 & 79205400 & 7560 & 43203600 & 20520 & 19800 & 18450 & 17100 & 16200 & 9450 \\
\hline Gross benefit $(\$ / \mathrm{ha})$ & 1555 & 51337 & 802 & 1913 & 2020 & 2035 & 1881 & 17421188 & 2041 & 1166972 & 3488 & 3366 & 3137 & 73762 & 3564 & 2079 \\
\hline Cost of Poultry manure $(\$ /$ ha $)$ & 70 & $0 \quad 70$ & 70 & 70 & 70 & 70 & 70 & $70 \quad 70$ & 70 & $\begin{array}{ll}70 & 70\end{array}$ & 70 & 70 & 70 & 70 & 70 & 70 \\
\hline Labour cost poultry manure appl. (\$/ha) & 50 & $0 \quad 50$ & 50 & 50 & 50 & 50 & 50 & $50 \quad 50$ & 50 & $50 \quad 50$ & 50 & 50 & 50 & 50 & 50 & 50 \\
\hline Chemical Fertilizer $(\$)$ & 60 & $0 \quad 60$ & 60 & 60 & 60 & 60 & 60 & $60 \quad 60$ & 60 & $60 \quad 60$ & 60 & 60 & 60 & 60 & 60 & 60 \\
\hline Labour cost for application of Fert.(\$/ha) & 11 & 111 & 11 & 11 & 11 & 11 & 11 & $11 \quad 11$ & 11 & $11 \quad 11$ & 11 & 11 & 11 & 11 & 11 & 11 \\
\hline land clearing $(\$ / \mathrm{ha})$ & 17 & $7 \quad 17$ & 17 & 17 & 17 & 17 & 17 & $17 \quad 17$ & 17 & $17 \quad 17$ & 17 & 17 & 17 & 17 & 17 & 17 \\
\hline Construction of ridg & 50 & $0 \quad 50$ & 50 & 50 & 50 & 50 & 50 & $50 \quad 50$ & 33 & 33 & 33 & 33 & 33 & 33 & 33 & 33 \\
\hline Cost of seec & 383 & 3383 & 383 & 127 & 127 & 127 & 255 & $255 \quad 255$ & 383 & $383 \quad 383$ & 127 & 127 & 127 & 255 & 255 & 255 \\
\hline Labour cost of planting $(\$ / \mathrm{ha})$ & 47 & $7 \quad 47$ & 47 & 47 & 47 & 47 & 47 & 47 & 47 & $47 \quad 47$ & 47 & 47 & 47 & 47 & 47 & 47 \\
\hline Cost of stakes $(\$ / h a)$ & 83 & 342 & 0 & 83 & 42 & 0 & 83 & 42 & 83 & 42 & 83 & 42 & 0 & 83 & 42 & 0 \\
\hline Labour cost of staking $(\$ / \mathrm{ha})$ & 93 & 47 & 0 & 93 & 47 & 0 & 93 & 47 & 93 & 47 & 93 & 47 & 0 & 93 & 47 & 0 \\
\hline Cost of weeding and reshaping & 150 & $0 \quad 150$ & 150 & 150 & 150 & 150 & 150 & 150150 & 150 & 150150 & 150 & 150 & 150 & 150 & 150 & 150 \\
\hline Harvesting $\operatorname{cost}(\$ / \mathrm{ha})$ & 33 & 33 & 33 & 33 & 33 & 33 & 33 & 33 & 33 & 33 & 33 & 33 & 33 & 33 & 33 & 33 \\
\hline Total cost & 1048 & $8 \quad 960$ & 871 & 791 & 703 & 615 & 920 & 831743 & 1031 & $943 \quad 855$ & 775 & 686 & 598 & 903 & 815 & 726 \\
\hline Net benefit & 507 & 7377 & -69 & 1121 & 1317 & 1420 & 962 & 911445 & 1010 & $224 \quad 118$ & 2714 & 2680 & 2539 & 2859 & 2750 & 1353 \\
\hline \multirow[t]{2}{*}{ Benefit cost/Ratio } & 0.5 & $5 \quad 0.4$ & -0.1 & 1.4 & 1.9 & 2.3 & 1 & 1.10 .6 & 1 & 0.20 .1 & 3.5 & 3.9 & 4.2 & 3.2 & 3.4 & 1.9 \\
\hline & \multicolumn{16}{|c|}{2013 Trellis/Minimum staking option with $30 \%$ number of vertical staking option } \\
\hline Location & \multicolumn{8}{|c|}{ Fumesua } & \multicolumn{8}{|c|}{ Ejura } \\
\hline Yam Variety & \multicolumn{3}{|c|}{ Dente } & \multicolumn{3}{|c|}{ Water yam } & \multicolumn{2}{|c|}{ TDR95/19177 } & \multicolumn{2}{|r|}{ Dente } & \multicolumn{3}{|c|}{ Water Yam } & TDF & $\mathrm{R} 95 / 19$ & 177 \\
\hline Staking Option & Vet & Trel 1 & NS & Vet & Trel & NS & Vet & Trel NS & Vet & Trel NS & Vet & Trel & NS & Vet & Trel & NS \\
\hline Average yields(kg/ha) & 14700 & 084005 & 53002 & 281002 & 28000 & 27600 & 13600 & 135008100 & 16700 & 104007300 & 28100 & 28000 & 27700 & 15600 & 15500 & 10100 \\
\hline Adjusted yield* & 13230 & 075604 & 47702 & 252902 & 25200 & 24840 & 12240 & 121507290 & 15030 & 93606570 & 25290 & 25200 & 24930 & 14040 & 13950 & 9090 \\
\hline Gross benefit(\$/ha) & 4366 & 62495 & 1574 & 5058 & 5040 & 4968 & 3305 & 32811968 & 4960 & 30892168 & 5058 & 5040 & 4968 & 3791 & 3767 & 2454 \\
\hline Cost of Poultry manure $(\$ / \mathrm{ha})$ & 83 & 383 & 83 & 83 & 83 & 83 & 83 & 83 & 83 & 83 & 83 & 83 & 83 & 83 & 83 & 83 \\
\hline Labour cost poultry manure appl. (\$/ha) & 50 & $0 \quad 50$ & 50 & 50 & 50 & 50 & 50 & 50 & 50 & $50 \quad 50$ & 50 & 50 & 50 & 50 & 50 & 50 \\
\hline Chemical Fertilizer $(\$)$ & 70 & 070 & 70 & 70 & 70 & 70 & 70 & 70 & 70 & $70 \quad 70$ & 70 & 70 & 70 & 70 & 70 & 70 \\
\hline Labour cost for application of Fert.(\$/ha) & 13 & 313 & 13 & 13 & 13 & 13 & 13 & 13 & 13 & $13 \quad 13$ & 13 & 13 & 13 & 13 & 13 & 13 \\
\hline Land clearing(\$/ha) & 20 & $0 \quad 20$ & 20 & 20 & 20 & 20 & 20 & 20 & 20 & 20 & 20 & 20 & 20 & 20 & 20 & 20 \\
\hline Construction of ridges $(\$ / \mathrm{ha})$ & 40 & $0 \quad 40$ & 40 & 40 & 40 & 40 & 40 & $40 \quad 40$ & 40 & $40 \quad 40$ & 40 & 40 & 40 & 40 & 40 & 40 \\
\hline Cost of seed yam $(\$)$ & 433 & 3433 & 433 & 133 & 133 & 133 & 283 & $283 \quad 283$ & 433 & $433 \quad 433$ & 133 & 133 & 133 & 283 & 283 & 283 \\
\hline Labour cost of planting $(\mathrm{S} / \mathrm{ha})$ & 50 & $0 \quad 50$ & 50 & 50 & 50 & 50 & 50 & 50 & 50 & $50 \quad 50$ & 50 & 50 & 50 & 50 & 50 & 50 \\
\hline Cost of stakes(\$/ha) & 90 & $0 \quad 27$ & 0 & 90 & 27 & 0 & 90 & 27 & 90 & 27 & 90 & 27 & 0 & 90 & 27 & 0 \\
\hline Labour cost of staking $(\$ / \mathrm{ha})$ & 93 & 330 & 0 & 93 & 30 & 0 & 93 & 30 & 93 & 30 & 93 & 30 & 0 & 93 & 30 & 0 \\
\hline Cost of weeding and reshaping $(\$ / h a)$ & 160 & $0 \quad 160$ & 160 & 160 & 160 & 160 & 160 & 160160 & 160 & 160160 & 160 & 160 & 160 & 160 & 160 & 160 \\
\hline Harvesting $\operatorname{cost}(\$ / \mathrm{ha})$ & 40 & $0 \quad 40$ & 40 & 40 & 40 & 40 & 40 & 40 & 40 & 40 & 40 & 40 & 40 & 40 & 40 & 40 \\
\hline Total cost that vary & 1143 & 31017 & 960 & 843 & 717 & 660 & 993 & $867 \quad 810$ & 1143 & 1017960 & 843 & 717 & 660 & 993 & 867 & 810 \\
\hline Net benefit & 3223 & 31478 & 614 & 4215 & 4323 & 4308 & 2311 & 24141158 & 3817 & 20721208 & 4215 & 4323 & 4308 & 2797 & 2900 & 1644 \\
\hline Benefit cost/Ratio & 2.8 & $\begin{array}{ll}8 & 1.5 \\
\end{array}$ & 0.6 & 5 & 6 & 6.5 & 2.3 & $2.8 \quad 1.4$ & 3.4 & $2.1 \quad 1.3$ & 5 & 6 & 6.5 & 2.8 & 3.3 & 2 \\
\hline
\end{tabular}

NB:* Average yield adjusted 10\%; Farm gate price per kg of Dente in $2012=$ us $\$ 0.27$; Farm gate price per kg of water yam in $2012=$ US\$ 0.17 ; Farm gate price per kg of TDR95/19177 in 2012 is assumed to be average for Dente and Water yam = us\$ 0.22; NS, Trel and Vet: No staking, Trellis/minimum and Vertical staking options respectively. Trellis/minimum staking had 50\% the number of stakes used in vertical staking. NB:* Average yield adjusted $10 \%$; Farm gate price per kg of Dente in $2013=$ us $\$ 1.33$; Farm gate price per $\mathrm{kg}$ of water yam in $2013=\mathrm{us} \$ 0.22$; Farm gate price per kg of TDR95/19177 in 2013 is assumed to be average for Dente and Water yam $=$ us $\$ 0.27$; NS, Trel and Vet; No staking, Trellis/minimum and Vertical staking options respectively. Trellis/minimum staking had $30 \%$ the number of stakes used in vertical staking. 


\section{Discussion}

Generally, the average tuber yields were higher in $2013(17.8 \mathrm{t} / \mathrm{ha})$ as compared to $2012(11.6 \mathrm{t} / \mathrm{ha})$ (Figures 1a, $1 \mathrm{~b}, 2 \mathrm{a}$ and $2 \mathrm{~b}$ ). This might be due to the more total rainfall and lower yam mosaic virus infection in 2013 as compared to 2012. The results suggested that the influence of staking option on leaf biomass, disease infection and tuber yields is more dependent on the yam variety and therefore breeding and agronomic techniques can be used to at least reduce the number of stakes needed in production. In both locations, no significant differences were observed in the yields and virus infection of water yam irrespective of the staking option (Figures 1a, 1b, 2a $\& 2 \mathrm{~b}$ ). This might be due to the vigorous growth and biomass production of water yam as compared to Dente and TDR95/19771 (Figures 3a \& 3b), making the staking option have little effect on sunlight interception abilities of the plant (Diby et al., 2011; Asante, 1996). Diby et al. (2011) observed in a study that the higher leaf area index of water yam (Dioscorea alata) as compared to Dente/white yam (Dioscorea rutundata), served as advantage to capture sunlight to produce more yields. In addition, virus incidence and severity on water yam was relatively low as compared to the other two varieties irrespective of the staking options used (Table 2). Thus, virus infection had little effect on water yam growth and yields. With these observations, farmers who are into water yam production can be encouraged to grow them without staking to take away the labour associated with staking.

The significant $(P \leq 0.05)$ influence of staking options on the biomass, disease infection and tuber yields of Dente and TDR95/19177 yam varieties irrespective of the location indicates the crucial role staking plays in the Rotundata family. Yam mosaic virus is reported to cause a decline in yields of yam especially the Rotundata species (IITA, 1981; Amusa et al., 2003). The significantly $(P \leq 0.05)$ higher yam mosaic virus infection of the non-staked yam compared to the other staking options of the two white yam varieties used in the study (Dente and TDR95/19177) (Table 2) might have contributed to the low leaf and vine production (Figures 3a and 3b). This observation might have led to the significantly lower tuber yields of the non-staked options compared to the other staking options for Dente and TDR95/19177 in both locations and years (Figures 1a, 1b, 2a and 2b).

However, in most cases there were no significant differences in the virus infection and tuber yield of TDR 95/19177 under trellis (both 50\% and 30\% number of stakes) and vertical staking options for both locations (Figures 1a, 1b, 2a and 2b). This suggests, the production of TDR95/19177 can be sustained at least under minimal staking (30-50\% stakes) condition as compared to Dente, which seems would need optimum/vertical staking to obtain optimum yield. From the study, it seems breeding for Rotundata lines tolerant to virus disease and ability to produce high biomass under no staking would be the way forward in achieving sustainable yam production without staking.

The benefit cost ratio of the economic analysis has generally confirmed that it is more profitable to produce water yam and TDR95/19177 under no staking and trellis (30\% and 50\% number of optimum staking) respectively in both locations (Table 3). This is evidenced in a benefit cost ratio of 1.0:1 and 3.4:1 for TDR95/19177 in Fumesua and Ejura respectively (Table 3). Thus, a farmer will accrue US\$ 1.00 plus an additional US\$ 2.40 if he/she invested US\$ 1.00/ha cultivating TDR95/19177 variety using trellis/reduced stakes at Ejura. The farmer will still have better benefits at Fumesua if he/she opted to plant TDR95/19177 under trellis/reduced staking. If he/she invested US\$ 1.00 he /she would get back the US\$ 1.00 invested and additional US\$ 0.10 (Table 3). Reducing the number of stakes by $70 \%$ increases the farmers' profit further, a benefit cost ratio of 2.8:1 and 3.3:1 at Fumesua and Ejura (Table 3). This implies when a farmer invest US\$ 1.00 in cultivating TDR95/19177 variety using trellis at Fumesua he/she would accrue US\$ 1.00 and additional profit of US\$ 1.80 . However if a similar investment is done at Ejura, the farmer would accrue a profit of US\$2.30 and the US\$ 1.00 invested. The study has demonstrated that with the appropriate selection and breeding of yam variety, there is hope of at least sustaining yam production on $30-50 \%$ number of stakes compared with the current optimum staking practice, if not under no staking. This would reduce the drudgery associated with the search for stakes and pressure on the forest to address the problem of deforestation.

\section{Conclusions}

Results from the study have revealed, it is more profitable to produce water yam under no staking. The number of stakes currently being used in yam production can be reduced by $50-70 \%$ to sustain the yield of TDR95/19177. No staking of TDR95/19177 yam line resulted in about 37-45\% yield reduction in both locations, thus further breeding would be required in developing varieties with high yields and virus disease resistance/tolerance under no staking. Promotion of water yam production under no staking option would require intensive education of farmers using demonstration plots. Further studies would be needed in the estimation and quantification of environmental savings/service associated with the use of the no staking option as against the use of other staking 
options in yam production. It is anticipated, that the sum of the environmental savings and the yield of the no staking option would merit its use. The study has suggested significant reduction $(50-70 \%)$ in the number of stakes used in yam production is possible. This would greatly reduce the contribution of yam production to deforestation in the face of climate change.

\section{Acknowledgements}

The authors are grateful to the West Africa Agricultural Productivity Programme (WAAPP) for providing financial support for the study. The technical support from CSIR-CRI staff Messers S. Obeng Antwi, S. Ahmed, D. Osei is appreciated.

\section{References}

Akwag, A. A., Berchie, J. N., Echavez, M. L., Dapaah, H. K., Kebede, T., Njue, S. W., ... Labrada, H. R. (2000). Sustainable Farming Practices- Towards Reducing the Expansion of the Forest Savanna Trasitional Zone of the Sekyere-West and Ejura-Sekyeredumase Districts of the Ashanti Region of Ghana. International Center for Development Oriented Research in Agriculture and Crops Research Institute, Working Document Series 86 , Ghana.

Adu, S. V., \& Asiamah, R. D. (1992). Soils of the Ayensu-Densu Basin, Central, Eastern and Greater Accra Regions of Ghana. Council for Scientific and Industrial Research (CSIR) - Soil Research Institute Memoir (No. 9, p. 117).

Amusa, N. A., Adegbita, A. A., Muhammed, S., \& Dalyewu, R. (2003). Yam diseases and its management in Nigeria. Afr. J. Biotech, 2, 497-502.

Asante, A. K. (1996). Use of bast fibre plants as staking materials for yam production in the Guinea Savanna zones of Ghana. Ghana Journal of Agricultural Science, 28-29, 99-103.

Asafu-Agyei, J. N., Ahenkora, K., Banful, B., \& Ennin-Kwabiah, S. (1997). Sustaining Food Production in Ghana: the Role of Cereal/Legume Based Cropping Systems. In T. Bezuneh, A. M. Emechebe, J. Sedge \& M. Ouedrago (Eds.), Technology options for sustainable agriculture in Sub-Saharan Africa (pp. 409-416). Publication of the Semi-Arid Food Grain Research and Development Agency (SAFGRAD) of the scientific, technical and research commission of OAU, Ouagadougou, Burkina Faso.

Diby, L. N., Sangakkara, R., Tie, B. T., Girardin, O., \& Frossard, E. (2011). Growth and Nutrient Use Efficiencies of Yams (Dioscorea spp.) Grown in Two Contrasting Soils of West Africa. International Journal of Agronomy. http://dx.doi.org/10.1155/2011/175958

Ennin, S. A., Otoo, E., \& Tetteh, F. M. (2009). Ridging, a Mechanized Alternative to Mounding for Yam and Cassava Production. West African Journal of Applied Ecology, 15.

Ennin, S. A., Isaaka, R. N., Acheampong, P. P., Numafo, M., \& Owusu Danquah, E. (2014). Mechanization, Fertilization and Staking Options for Environmentally Sound Yam Production. African Journal Agricultural Research, 9(29), 2222-2230. http://dx.doi.org/10.5897/AJAR2014.8487

Ennin, S. A., Dapaah, H. K., \& Abaidoo, R. C. (2004). Nitrogen Credits from Cowpea, Soybean, Groundnut and Mucuna to Maize in Rotation. West Africa Journal of Applied Ecology, 6, 5-74.

Eze, S. C., \& Orkwor, G. C. (2010). Studies on effects of mineral fertilizer, organic manure and cultivar on the yield and storability of Yam (Dioscorea rotundata Poir). African Journal of Food Agriculture, Nutrition and Development, 10, 2755-2771.

FAOSTAT. (2012). FAO Statistics Division 2012.

Ferguson, T. U., \& Haynes, P. H. (1970). The response of yams (Dioscorea spp.) to nitrogen, phosphorus, potassium and organic fertilizers. In D. L. Plucknett (Ed.), Tropical Root and Tuber Crops Tomorrow: Proceedings of the 2nd International Symposium on Tropical Root and Tuber Crops (Hawaii, 1970) (Vol. I, pp. 93-96). Honolulu, Hawaii: College of Tropical Agriculture, University of Hawaii.

Garrity, D. P. (2004). Agroforestry and the Achievement of the Millennium Development Goals. In P. K. Nair, M. R. Rao \& L. E. Buck (Eds), New Vistas in Agroforestry, Kluwer Academic Publishers, Netherland.

International Institute of Tropical Agriculture (IITA). (1981). Root and tuber improvement program (pp.49-80). Ann. Report. IITA, Ibadan, Nigeria.

International Institute of Tropical Agriculture (IITA). (2010). Status of Yam Research in Ghana. A report submitted by College of Agriculture \& Natural Resources, Kwame Nkrumah University of Science \& Technology, 
Kumasi, Ghana to the International Institute of Tropical Agriculture, Ibadan, Nigeria.

Kombiok, J. M., Dogbe, W., \& Kanton, R. (1997). Cropping Systems and Long-Term Soil Fertility Management for Sustainable Agriculture in Northern Ghana. In T. Bezuneh, A. M. Emechebe, J. Sedge \& M. Ouedrago (Eds.), Technology options for sustainable agriculture in Sub-Saharan Africa (pp. 417-424). Publication of the Semi-Arid Food Grain Research and Development Agency (SAFGRAD) of the scientific, technical and research commission of OAU, Ouagadougou, Burkina Faso.

Le Buanec, B. (1972). Absorption and uptake of major nutrients by yams. GERDAT. Groupement d'Etudes et de Rechèrche pour le Dévelopment de l'Agronomie Tropicale. IRAT. Institut de Rechèrches Agronomiques Tropicales et des Cultures Vivrières. Nogent-sur-Marne (Côte d' Ivoire) Reunion d'Agronomie de l'IRAT: 1974/07/04-12; Paris (FRA) Bouaké (CIV): GERDAT-IRAT.

Mignouna, H. D., Njukeng, P., Abang, M. M., \& Asiedu, R. (2001). Inheritance of resistance to yam mosaic potyvirus in white yam (Dioscorea rotundata). Theoretical and Applied Genetics, 103, 1196-2000. http://dx.doi.org/10.1007/s001220100728

Ndegwe, A. A., Ikpe, F. N., Gbosi, S. D., \& Jaja, E. T. (1990). Effect of staking method on yield and its components in sole cropped white guinea yam (Dioscorea rotundata Poir) in high rainfall area of Nigeria. Trop. Agric. Trin, 67(1), 29-32.

Odu, B. O., Asiedu, R., Hughes, J. d'A., Shoyinka, S. A., \& Oladiran, A. O. (2004). Identification of resistance to yam mosaic virus (YMV), genus Potyvirus in white Guinea yam (Dioscorea rotundata). Field Crops Research, 89(1), 97-105. http://dx.doi.org/10.1016/j.fcr.2004.01.009

Otoo, E., Anchirina, V. M., Ennin, S. A., \& Asiedu, R. (2008). Sustainable yam production in Ghana the non-staking option. Journal of Food, Agriculture \& Environment, 6(3\&4), 391-396.

Policy Planning, Monitoring \& Evaluation (PPMED). (2007). Agriculture in Ghana-Facts and Figures. Policy Planning, monitoring and Evaluation. Ministry of Food and Agriculture, Ghana.

Quansah, C., Drechsel, P., Yirenkyi, B. B., \& Asante-Mensah, S. (2001). Farmers' perception and management of soil organic matter - a case study from West Africa. Nutrient Cycling in Agroforestry Systems, 61, 205-213. http://dx.doi.org/10.1023/A:1013337421594

Wholey, D. V., \& Haynes, P. H. (1971). A yam staking systems for Trinidad. Wld Crops, 23, 123-126.

\section{Copyrights}

Copyright for this article is retained by the author(s), with first publication rights granted to the journal.

This is an open-access article distributed under the terms and conditions of the Creative Commons Attribution license (http://creativecommons.org/licenses/by/3.0/). 